ISSN 1392-3196 / e-ISSN 2335-8947

Zemdirbyste-Agriculture, vol. 103, No. 2 (2016), p. 193-198

DOI 10.13080/z-a.2016.103.025

\title{
Secondary metabolites in Hypericum species and their distribution in different plant parts
}

\author{
Mehmet Serhat ODABAS ${ }^{1}$, Jolita RADUSIENE ${ }^{2}$, Liudas IVANAUSKAS ${ }^{3}$, Valdas JAKSTAS ${ }^{3}$, \\ Necdet CAMAS ${ }^{1}$, Samim KAYIKCI ${ }^{4}$ \\ ${ }^{1}$ Vocational High School of Bafra, Ondokuz Mayis University \\ Samsun, Turkey \\ E-mail:mserhat@omu.edu.tr \\ ${ }^{2}$ Institute of Botany, Nature Research Centre \\ Akademijos 2, Vilnius, Lithuania \\ ${ }^{3}$ Medical Academy, Lithuanian University of Health Sciences \\ A. Mickevičiaus 9, Kaunas, Lithuania \\ ${ }^{4}$ Mustafa Kemal University \\ Hatay, Turkey
}

\begin{abstract}
The genus Hypericum (Hypericaceae) has attracted remarkable scientific interest as its members accumulate significant amounts of various bioactive compounds. In the current study, we investigated accumulation of several bioactive compounds in various parts of Hypericum hircinum L. subsp. majus (Ainton) N. Robson, H. pallens Banks et Sol., H. russeggeri (Fenzl) R. Keller and H. lanuginosum Lam. The plant materials were harvested at flowering, dissected into different tissues and subsequently subjected to high performance liquid chromatography (HPLC) analyses. Accumulation level of the investigated compounds varied greatly depending on species and plant parts. Among different plant tissues, flowers were found to be superior to leaves with respect to accumulation of the chemicals tested except for neochlorogenic, caffeic and 2,4-dihydroxybenzoic acids which were accumulated mainly in leaves. H. hircinum did not produce quercitrin or avicularin, H. lanuginosum did not accumulate hyperforins and caffeic acid, rutin was detected only in $H$. pallens.

For the first time, chemical profiles of these Turkish species of Hypericum were reported and the results are discussed from a phytochemical point of view. The present data could be helpful in selecting the future targets for phytochemical and biological studies on Hypericum genus as well as enriching our current knowledge about Hypericum chemistry.
\end{abstract}

Key words: chemical characterization, flavonols, Hypericum hircitum, H. lanuginosum, H. pallens, H. russeggeri, naphthodianthrones, phenolic acids, phloroglucinols.

\section{Introduction}

According to the most recent count by Crockett and Robson (2011), the genus Hypericum L. (Hypericaceae) includes 484 species that occur naturally on every continent in the world, except Antarctica. In particular, extracts of Hypericum perforatum L., the most abundant and well known species, are now widely used in Europe as a drug for the treatment of mild to moderate depression and all species of Hypericum have been used as sedatives, antiseptics and antispasmodics (Fiebich et al., 2011; Camas et al., 2014).

Hypericum hircinum L. subsp. majus (Ainton) $\mathrm{N}$. Robson is a widespread shrub which grows naturally in damp, shady places besides streams at moderate altitudes of Southern Turkey. Results from recent studies reporting the monoamine oxidases inhibitory (Chimenti et al., 2006), antimicrobial (Nogueira et al., 2013), antioxidant and antiproliferative (Quassinti et al., 2013; Bertoli et al., 2015) activities of $H$. hircinum point out the great potential of this species as a promising medicinal plant.

Hypericum pallens Banks et Sol. and Hypericum russeggeri (Fenzl) R. Keller are rare herbaceous perennials, which grow in calcareous and limestone rocks of high altitudes in Southern Turkey. Hypericum lanuginosum Lam. is an endemic species from Turkish flora, which grows wild in some calcareous and scrub zones of Southern Turkey. In contrast to $H$. hircinum, neither ethnomedicinal nor pharmacological reports on the last three species are available in the current literature. 
Phloroglucinol derivatives, naphthodianthrones, phenolic acids, flavonoids and essential oils are thought to be the main ingredients in Hypericum extracts, which possess a wide array of biological activities (Kasper et al., 2010). Among the chemicals, hypericins and hyperforins are considered to be synergistically responsible for the antidepressant activity of Hypericum extracts (Çirak, 2006; Du et al., 2006). Hyperforin also exhibits antiinflammatory (Feisst, Werz, 2004), antitumoral (Schwarz et al., 2003) and antiangiogenic (Dona et al., 2004) effects.

Hypericins, the naturally occurring red pigments have been reported to exhibit significant bioactivities namely, antiviral, antiretroviral, photodynamic, antibacterial, antidepressant and antitumoral activities (Guedes, Eriksson, 2005). Although hyperforin and hypericins have been reported to mainly contribute to the pharmacological effects of Hypericum extracts, flavonoids, which are well known as antioxidants have also made an important contribution to the antidepressant activity (Gastpar, Zeller, 2005; Cirak, 2007; Cirak et al., 2010; 2013 a; b; Bertoli et al., 2011; Khan et al., 2011).

The aerial parts of $H$. hircinum subsp. majus were reported to contain chlorogenic acid, rutin, hyperoside, isoquercetin, quercitrin, quercetin, hyperforin and hypericin in a previous investigation (Sagratini et al., 2008). In the present paper we aimed to complete chemical characterization of this species with the first detection of several new compounds namely, pseudohypericin, adhyperforin, neochlorogenic acid, caffeic acid, 2,4-dihydroxybenzoic acid amentoflavone, avicularin, $(+)$-catechin and (-)-epicatechin.

Besides, to our knowledge, no study has been done on the chemistry of $H$. pallens, $H$. russeggeri and $H$. lanuginosum. So in this study, we also aimed to describe these species chemically by investigating the presence of naphthodianthrones hypericin and pseudohypericin, phloroglucinol derivatives hyperforin and adhyperforin, the phenolic acids chlorogenic acid, neochlorogenic acid, caffeic acid, 2,4-dihydroxybenzoic acid, and the flavonoids amentoflavone, hyperoside, isoquercetrin, quercitrin, quercetin, avicularin, rutin, $(+)$-catechin and (-)-epicatechin in the three species of Hypericum for the first time.

\section{Materials and methods}

Chemicals. Solvents used were of high performance liquid chromatography (HPLC) grade and purchased from Roth GmbH (Germany). Water was filtered through the grade water preparation cartridge Millipore HPLC (Millipore, USA). Reference substances were purchased from ChromaDex (USA), Sigma-Aldrich (USA) and HWI ANALYTIK GmbH (Germany).
Plant materials. The aerial parts of Hypericum plants, which represent a total of 30 individuals for each species were collected at full flowering from Southern Turkey in June, 2015. The species names, their voucher numbers and geographical data of collection sites are shown in Table 1.

Voucher specimens were deposited in the herbarium of Faculty of Agriculture, Ondokuz Mayis University, Turkey. The top of 2/3 plants was harvested. The plant materials were dried at room temperature $\left(20 \pm 2^{\circ} \mathrm{C}\right)$, and after separated into different tissues subsequently assayed for chemical contents by HPLC.

Preparation of plant extracts. Air-dried plant material was mechanically ground with a laboratory mill to obtain a homogenous drug powder. Samples of approximately $0.1 \mathrm{~g}$ (weighed with $0.0001 \mathrm{~g}$ precision) were extracted in $10 \mathrm{ml}$ of $100 \%$ methanol by ultrasonication at $40^{\circ} \mathrm{C}$ for $30 \mathrm{~min}$ in a Sonorex Super model RK $225 \mathrm{H}$ ultrasonic bath. The prepared extracts were filtered through a membrane filter with pore size of $0.22 \mu \mathrm{m}$ (Carl Roth $\mathrm{GmbH}$, Germany) and kept in a refrigerator until analysis. The extracts for naphthodianthrones analysis were exposed to light under xenon lamp $\left(765 \mathrm{~W} \mathrm{~m}^{-2}\right)$ for $8 \mathrm{~min}$ due to the photoconversion of protohypericins into hypericins.

High performance liquid chromatography (HPLC) analysis and identification. A separation module system Waters Alliance 2695 (Waters Corporation, USA) equipped with Waters $2487 \mathrm{UV} / \mathrm{Vis}$ and Waters 996 PDA diode-array detectors were used for HPLC analysis. Data were analyzed using software chromatographic manager system Empower (Waters Corporation, USA).

Separation of flavonoids, epicatechin and hyperforin was carried out on SunFire C18 column $(3.5 \mu \mathrm{m}, 150 \times 3.0 \mathrm{~mm}$ internal diameter $)$ with $10 \mathrm{~mm}$ guard-precolumn. The binary gradient elution method was used for detection of corresponding compounds. The mobile phase consisted of water Milli-Q acidified with $0.3 \%$ phosphoric acid as eluent $\mathrm{A}$ and acetonitrile containing $0.3 \%$ phosphoric acid as eluent $\mathrm{B}$. The elution profile was used as follows: $0-12 \mathrm{~min} 16 \% \mathrm{~B}, 12-18 \mathrm{~min}$ (B 16 $\rightarrow 53 \%$ ), 18-18.1 min (B 53 $\rightarrow 97 \%$ ), 18.1-29 min (B $97 \rightarrow 97 \%$ ) and $29-30$ min (B 97 $\rightarrow 16 \%$ ). Flow rate was $0.6 \mathrm{~mL} \mathrm{~min}{ }^{-1}$ at a constant $25^{\circ} \mathrm{C}$ column temperature. The volume of extract injected was $10 \mu \mathrm{L}$. Peaks were detected at a wavelength range of $270-360 \mathrm{~nm}$.

The ACE C18 column $(5.0 \mu \mathrm{m}, 250 \times 4.6 \mathrm{~mm}$ internal diameter) (MAC-MOD Analytical Inc., USA) with guard-precolumn was used for separation of phenolic acids, catechin and hypericins. The mobile phase of gradient elution of phenolic acids and catechin was composed of eluent $\mathrm{A}$ - water acidified with $0.5 \%$ glacial acetic acid, and eluent $\mathrm{B}-$ acetonitrile. The separation was performed using the following program: $0-30 \min (\mathrm{B} 5 \rightarrow 35 \%$ ), 30-36 $\min (\mathrm{B} 35 \rightarrow 90 \%$ ) and

Table 1. Collection sites and habitat of the Hypericum species examined

\begin{tabular}{lcccccc}
\hline \multicolumn{1}{c}{ Species } & Voucher & \multicolumn{2}{c}{ Collection } & \multicolumn{2}{c}{ Latitude Longitude Elevation } \\
& numbers & sites & $\mathrm{N}$ & E & m & Habitat \\
\hline H. hircinum L. & OMUZF122 & Samandağ-Batiayaz & $36^{\circ} 11^{\prime}$ & $36^{\circ} 59^{\prime}$ & 450 & shady areas near streams \\
H. lanuginosum Lam. & OMUZF123 & Samandağ-Mağarac1k & $36^{\circ} 06^{\prime}$ & $35^{\circ} 56^{\prime}$ & 60 & calcareous rocks, Macchie \\
H. pallens Banks et Sol. & OMUZF124 & Samandağ-Mağarac1k & $36^{\circ} 06^{\prime}$ & $35^{\circ} 56^{\prime}$ & 60 & calcareous rocks \\
H. russeggeri (Fenzl) R. Keller OMUZF125 & Samandağ-Çevlik & $36^{\circ} 07^{\prime}$ & $35^{\circ} 55^{\prime}$ & 30 & calcareous rocks \\
\hline
\end{tabular}

Note. Species are listed alphabetically. 
36-37 min (B 90 $\rightarrow 5 \%$ ). The flow rate was $1.0 \mathrm{~mL} \mathrm{~min}^{-1}$ at $25^{\circ} \mathrm{C}$ column temperature. Peaks were detected at a wavelength range 277-324 $\mathrm{nm}$.

Hypericin and pseudohypericin were analyzed according to modified pharmacopoeial HPLC method (Anonymous, 2010). The mobile phase of isocratic elution of hypericin and pseudohypericin consisted of ethyl acetate, aqueous $0.1 \mathrm{M}$ sodium dihydrogen phosphate solution, adjusted to $\mathrm{pH} 2.0$ using phosphoric acid and methanol

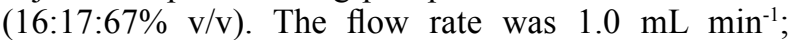
$20 \mu \mathrm{L}$ of extract was injected. Detection was performed at $560 \mathrm{~nm}$ wavelength at $40^{\circ} \mathrm{C}$ column temperature. Comparing retention times of samples with those of the reference standards identified chromatographic peaks. Furthermore, in order to confirm the identity of the eluted constituents, spectral characteristics of the eluting peaks were recorded with diode-array detector and compared with UV spectra of authentic standards.

Quantification of compounds was carried out by the external standard method. Standards stock solutions at a concentration of $1.0 \mathrm{mg} \mathrm{mL}^{-1}$ were prepared freshly in methanol and diluted in appropriate quantities to obtain a set of corresponding concentration ranges for the study of linearity. A calibration curve for each of the compounds was constructed by plotting peak areas versus the respective compound concentration and calculated by linear regression analysis. The regression coefficients $\left(r^{2}\right.$ $\geq 0.999$ ) of all calibration curves indicated that, in the ranges of standard concentrations analyzed, the peak areas were directly proportional to the concentrations and, thus, methods presented adequate linearity. The precision of the method was demonstrated for all analyses, since all the obtained relative standard deviation (SD) values were lower than $5 \%$. The concentration of compounds was expressed as $\mathrm{mg} \mathrm{g}^{-1}$ dry mass (DM).

\section{Results and discussion}

Results from HPLC analyses of methanolic plant extracts revealed different chemical composition profiles and significant quantitative differences for $H$. hircinum subsp. majus, $H$. pallens, $H$. russeggeri and $H$. lanuginosum. Occurrence and accumulation level of the tested compounds varied greatly depending on species and plant parts. Among different plant tissues, generally lower levels of chemical accumulation were observed in stems and some compound, namely, hyperforin, adhyperforin, caffeic acid, 2,4-dihydroxybenzoic acid and avicularin were not detected in this tissue. Flowers were found to be superior to leaves with respect to accumulation of the chemicals tested except for neochlorogenic, caffeic and 2,4-dihydroxybenzoic acids which were accumulated mainly in leaves (Tables 2 and 3 ).

Regarding the quantitative amount of tested compounds, hypericinandpseudohypericinconcentrations varied from trace amounts in flowers of $H$. hircinum subsp. majus to 1.05 and $1.74 \mathrm{mg} \mathrm{g}^{-1} \mathrm{DM}$ in flowers of $H$. pallens, respectively, and those compounds were generally absent in leaves as well as stems. Hyperforin and adhyperforin were not detected in $H$. lanuginosum and similar to hypericins, these compounds reached their highest accumulation levels in flowers of $H$. pallens (3.02 and $1.25 \mathrm{mg} \mathrm{g}^{-1} \mathrm{DM}$, respectively). Chlorogenic and neochlorogenic acids contents ranged from 0.01 and $0.07 \mathrm{mg} \mathrm{g}^{-1} \mathrm{DM}$ in stems of $H$. russeggeri to 76.36 and $5.48 \mathrm{mg} \mathrm{g}^{-1} \mathrm{DM}$ in leaves of $H$. pallens, respectively.

2,4-dihydroxybenzoic acid accumulation was the highest in leaves of $H$. hircinum subsp. majus $\left(0.54 \mathrm{mg} \mathrm{g}^{-1} \mathrm{DM}\right)$ and was not observed in flowers of $H$. pallens whose leaves yielded this compound in small amount (0.05 $\left.\mathrm{mg} \mathrm{g}^{-1} \mathrm{DM}\right)$. Caffeic acid accumulation was observed only in leaves of $H$. hircinum subsp. majus and H. pallens ( 0.01 and $0.05 \mathrm{mg} \mathrm{g}^{-1} \mathrm{DM}$, respectively). Leaves of $H$. russeggeri did not accumulate amentoflavone and the highest concentration level of this compound was observed in flowers of $H$. hircinum subsp. majus $(2.79$ $\mathrm{mg} \mathrm{g}^{-1} \mathrm{DM}$ ) (Table 2).

Hyperoside, isoquercetin, quercetin, $(+)$-catechin and $(-)$-epicatechin were detected in all parts of Hypericum plants studied. Leaves of $H$. lanuginosum produced the highest level of hyperoside, isoquercetin, quercetin, $(+)$-catechin and (-)-epicatechin - 5.36, 2.01, $1.96,1.27$ and $3.90 \mathrm{mg} \mathrm{g}^{-1} \mathrm{DM}$, respectively. The lowest accumulation levels of hyperoside, isoquercetin, quercetin and $(+)$-catechin were observed in stems of $H$. russeggeri $\left(0.13,0.04,0.01\right.$ and $0.01 \mathrm{mg} \mathrm{g}^{-1} \mathrm{DM}$, respectively) and in leaves of the same species for (-)-epicatechin $\left(0.36 \mathrm{mg} \mathrm{g}^{-1} \mathrm{DM}\right)$

Table 2. Hypericin (1), pseudohypericin (2), hyperforin (3), adhyperforin (4), chlorogenic acid (5), neochlorogenic acid (6), caffeic acid (7), 2,4-dihydroxybenzoic acid (8) and amentoflavone (9) contents ( $\left.\mathrm{mg} \mathrm{g}^{-1} \mathrm{DM}\right)$ in different plant parts of some Hypericum species from Southern Turkey

\begin{tabular}{|c|c|c|c|c|c|c|c|c|c|c|}
\hline \multirow{2}{*}{ Species } & \multirow{2}{*}{ Plant parts } & \multicolumn{9}{|c|}{ Compounds } \\
\hline & & 1 & 2 & 3 & 4 & 5 & 6 & 7 & 8 & 9 \\
\hline \multirow{3}{*}{$\begin{array}{l}\text { H. hircinum L. subsp. } \\
\text { majus (Ainton) }\end{array}$} & stem & - & - & - & - & 0.65 & 0.14 & - & - & - \\
\hline & leaf & - & - & - & - & 3.21 & 1.12 & 0.01 & $0.54 *$ & 1.27 \\
\hline & flower & $\begin{array}{c}\text { trace } \\
\text { amount }\end{array}$ & $\begin{array}{c}\text { trace } \\
\text { amount }\end{array}$ & 0.02 & 0.01 & 4.19 & 0.12 & - & 0.10 & $2.79 *$ \\
\hline \multirow{3}{*}{ H. lanuginosum Lam. } & stem & - & - & - & - & 0.02 & 0.21 & - & - & - \\
\hline & leaf & - & - & - & - & 0.82 & $2.03 *$ & - & 0.22 & 0.05 \\
\hline & flower & 0.01 & 0.04 & - & - & 1.26 & 1.82 & - & 0.13 & 0.42 \\
\hline \multirow{3}{*}{ H. pallens Banks et Sol. } & stem & 0.01 & 0.02 & - & - & 5.59 & 0.31 & - & - & 0.01 \\
\hline & leaf & $0.62 *$ & $0.69 *$ & $1.25 *$ & 0.12 & $76.36 *$ & $5.48 *$ & $0.05 *$ & 0.05 & 0.04 \\
\hline & flower & $1.05 *$ & $1.74 *$ & $3.02 *$ & 1.25 & $11.56 *$ & 1.31 & - & - & 0.86 \\
\hline \multirow{3}{*}{ H. russeggeri (Fenzl) } & stem & - & - & - & - & 0.01 & 0.07 & - & - & - \\
\hline & leaf & - & - & - & - & 0.05 & 2.91* & - & 0.24 & - \\
\hline & flower & 0.01 & 0.01 & 0.02 & 0.02 & 0.29 & 1.35 & - & 0.16 & 0.25 \\
\hline
\end{tabular}

Note. Species are listed alphabetically; ${ }^{*}-P<0.05$ was considered statistically significant. 
Table 3. Hyperoside (10), isoquercetin (11), quercitrin (12), quercetin (13), avicularin (14), rutin (15), (+)-catechin (16) and (-)-epicatechin (17) contents ( $\left.\mathrm{mg} \mathrm{g}^{-1} \mathrm{DM}\right)$ in different plant parts of some Hypericum species from Southern Turkey

\begin{tabular}{|c|c|c|c|c|c|c|c|c|c|}
\hline \multirow{2}{*}{ Species } & \multirow{2}{*}{ Plant parts } & \multicolumn{8}{|c|}{ Compounds } \\
\hline & & 10 & 11 & 12 & 13 & 14 & 15 & 16 & 17 \\
\hline \multirow{3}{*}{$\begin{array}{l}\text { H. hircinum L. subsp. } \\
\text { majus (Ainton) }\end{array}$} & stem & 0.47 & 0.24 & - & 0.14 & - & - & 0.83 & 0.43 \\
\hline & leaf & 0.78 & 0.27 & - & 0.27 & - & - & 0.97 & 1.27 \\
\hline & flower & 1.14 & 1.42 & - & $1.36 *$ & - & - & $1.34 \%$ & $1.99 *$ \\
\hline \multirow{3}{*}{ H. lanuginosum Lam. } & stem & 0.50 & 0.17 & 0.77 & 0.15 & - & - & 0.01 & 1.25 \\
\hline & leaf & 1.61 & 0.48 & $2.27 *$ & 0.12 & - & - & 0.19 & 1.13 \\
\hline & flower & $5.36 *$ & $2.01 *$ & $2.96 *$ & $1.96 *$ & 0.09 & - & $1.27 *$ & $3.90 *$ \\
\hline \multirow{3}{*}{ H. pallens Banks et Sol. } & stem & 0.36 & 0.62 & 0.85 & 0.04 & - & 0.93 & 0.66 & 0.88 \\
\hline & leaf & 1.02 & 1.42 & 1.15 & 0.15 & - & $4.45 *$ & 0.02 & 1.17 \\
\hline & flower & 1.97 & $1.78 *$ & $3.32 *$ & 0.85 & $0.38 *$ & 1.17 & $1.23 *$ & $2.18 *$ \\
\hline \multirow{3}{*}{ H. russeggeri (Fenzl) } & stem & 0.13 & 0.04 & 0.37 & 0.01 & - & - & 0.01 & 0.48 \\
\hline & leaf & 0.44 & 0.12 & 1.49 & 0.06 & - & - & 0.02 & 0.36 \\
\hline & flower & 1.99 & 0.84 & $2.31 \%$ & 0.24 & 0.06 & - & 0.04 & $1.74 *$ \\
\hline
\end{tabular}

Note. Species are listed alphabetically; ${ }^{*}-P<0.05$ was considered statistically significant.

Rutin was detected only in $H$. pallens whose leaves accumulated the highest amount of this compound (4.45 $\left.\mathrm{mg} \mathrm{g}^{-1} \mathrm{DM}\right)$. H. hircinum subsp. majus did not produce avicularin and this compound was detectable only in flowers of the other investigated species in low amounts. $H$. hircinum subsp. majus also did not produce quercitrin whose yield ranged from $0.37 \mathrm{mg} \mathrm{g}^{-1} \mathrm{DM}$ in stems of $H$. russeggeri to $3.32 \mathrm{mg} \mathrm{g}^{-1} \mathrm{DM}$ in flowers of H. pallens (Table 3).

Morphologically, three kinds of secretory structures, including light glands, dark glands and secretory canals are facilitated to characterize Hypericum plants (Ciccarelli et al., 2001). These structures are accumulation and/or synthesis sites for different kinds of phytochemicals. For example, hypericins are thought to be present only in the species of Hypericum whose aerial parts bear dark glands (Lu et al., 2001) and a positive correlation was reported in dark gland density and hypericin content of leaf in $H$. perforatum, $H$. pruinatum Boiss. \& Balansa and H. aviculariifolium subsp. depilatum var. depilatum (Freyn and Bornm.) Robson var. depilatum (Cirak et al., 2006). The localization of the secretory structures varies greatly among plant tissues, and for that reason, the levels of phytochemicals in a particular Hypericum tissue depend on the relative abundance of these secretory structures on the harvested material (Zobayed et al., 2006). As a result, organ-dependence of a given chemical is common among Hypericum species and this phenomenon could explain the great variation observed in the chemical contents among the species investigated as well as their different tissues.

All values are presented as the mean \pm standard error (SE) of the mean of $n$ observations, being $n$ the number of studied plants. The results in each group were compared by one-way analysis of variance $(A N O V A)$ for multiple comparisons. $P<0.05$ was considered statistically significant. Software MATLAB (MatLab ${ }^{\circledR}$ 8.1.0.604 R2013a) was used for statistical analysis (Table 4).

Accumulation patterns of the chemicals in leaves and flowers of the species in the present paper corresponded in the same way to each other and matched largely those described for other Hypericum species. In $H$. perforatum, the well known and most studied species of Hypericaceae, flowers accumulated larger amounts of hypericin, hyperforin, rutin, quercetin and quercitrin and leaves had the highest level of hyperoside (Bagdonaite et al., 2010). Similarly, $H$. origanifolium Willd. and $H$. perfoliatum L. accumulated quercitrin, rutin as well as hypericin, pseudohypericin and hyperforin mainly in their floral buds and flowers, while their leaves produced higher amounts of quercetin, chlorogenic acid and hyperoside (Cirak et al., 2007). Flowers of $H$. montbretii Spach accumulated the highest level of hyperforin, hypericin and apigenin-7-O-glucoside and

Table 4. Descriptive statistics for compound in different plant parts of some Hypericum species

\begin{tabular}{|c|c|c|c|c|c|}
\hline & \multirow{2}{*}{$\begin{array}{c}\text { Minimum } \\
\text { statistic }\end{array}$} & \multirow{2}{*}{$\begin{array}{c}\text { Maximum } \\
\text { statistic }\end{array}$} & \multicolumn{2}{|c|}{ Mean } & \multirow{2}{*}{$\frac{\mathrm{SD}}{\text { statistic }}$} \\
\hline & & & statistic & $\mathrm{SE}$ & \\
\hline Hypericin & 0.00 & 1.05 & 0.14 & 0.097 & 0.34 \\
\hline Pseudohypericin & 0.00 & 1.74 & 0.21 & 0.15 & 0.52 \\
\hline Hyperforin & 0.00 & 3.02 & 0.36 & 0.26 & 0.91 \\
\hline Adhyperforin & 0.00 & 1.25 & 0.12 & 0.10 & 0.36 \\
\hline Chlorogenic acid & 0.01 & 76.36 & 8.67 & 6.23 & 21.58 \\
\hline Neochlorogenic acid & 0.07 & 5.48 & 1.41 & 0.45 & 1.57 \\
\hline Caffeic acid & 0.00 & 0.05 & 0.01 & 0.001 & 0.01 \\
\hline 2,4-dihydroxybenzoic acid & 0.00 & 0.54 & 0.12 & 0.05 & 0.16 \\
\hline Amentoflavone & 0.00 & 2.79 & 0.47 & 0.24 & 0.84 \\
\hline Hyperoside & 0.13 & 5.36 & 1.31 & 0.41 & 1.42 \\
\hline Isoquercetin & 0.04 & 2.01 & 0.78 & 0.20 & 0.70 \\
\hline Quercitrin & 0.00 & 3.32 & 1.29 & 0.34 & 1.18 \\
\hline Quercetin & 0.01 & 1.96 & 0.45 & 0.18 & 0.62 \\
\hline Avicularin & 0.00 & 0.38 & 0.04 & 0.03 & 0.11 \\
\hline Rutin & 0.00 & 4.45 & 0.55 & 0.37 & 1.30 \\
\hline$(+)$-catechin & 0.01 & 1.34 & 0.55 & 0.16 & 0.56 \\
\hline$(-)$-epicatechin & 0.36 & 3.90 & 1.40 & 0.28 & 0.98 \\
\hline
\end{tabular}

$\mathrm{SD}$ - standard deviation, SE - standard error 
the highest accumulation level of chlorogenic acid was found in leaves (Cirak, Radusiene, 2007). Hypericin and pseudohypericin were detected only in flowers and leaves had the highest accumulation level of chlorogenic acid in $H$. scabrum L. and H. bupleuroides Gris. (Cirak et al., 2016). In wild and greenhouse-grown $H$. triquetrifolium Turra plants, flowers accumulated the highest level of hyperoside, quercetin and quercitrin; however, leaves produced higher amount of chlorogenic acid and isoquercetin (Cirak et al., 2013 a). Floral parts had the highest level of hypericin, pseudohypericin, quercitrine and quercetine and leaves accumulated the highest level of chlorogenic acid as well as rutin and hyperoside in $H$. aviculariifolium subsp. depilatum var. depilatum and H. orientale L. (Cirak et al., 2013 b).

Studies on identifying chemical profile may be useful for taxonomic analysis of the genus Hypericum (Crockett, Robson, 2011). Because only few morphological characters are available to distinguish between some sections, identifying the individual plants solely based on morphological characters is very difficult. In this regard, chemotaxonomic significance is attributed to some of the Hypericum chemicals such as naphthodianthrones hypericins (Kitanov, 2001), dimeric phloroglucinol uliginosin B (Ferraz et al., 2002), flavonoids hyperoside, quercetin, quercitrin (Cirak et al., 2010), rutin and mangiferin (Nunes et al., 2010). Thus, results of the present chemical investigation could be used as an additional tool for taxonomic identification of species in the genus although $H$. hircinum, $H$. lanuginosum, $H$. pallens and $H$. russeggeri fall into different sections within Hypericum genus, namely Androsaemum (Duhamel) Gordon, Adenosepalum Spach, Triadenioides Jaub. \& Spach. and Triadenia Spach. (Davis, 1988).

\section{Conclusion}

Increasing interest in recent years for using medicinal and aromatic plants in pharmaceutical, food, biotechnology and cosmetic industries all over the world has resulted in extensive efforts to discover new sources of potential bioactive phytochemicals. In this sense, the present screening data could be helpful in selecting the future targets of new sources of bioactive compounds of Hypericum species for phytochemical and biological studies as well as enriching our current knowledge about Hypericum genus chemistry. Besides, this is the first report describing the chemical profile of $H$. pallens, $H$. russeggeri and $H$. lanuginosum as well as the occurrence of several new compounds in $H$. hircinum subsp. majus. The present data are of great interest to reveal new sources of raw material as potential pharmaceuticals. The chemical evaluation of Hypericum species could be used as an additional tool in completing the taxonomy of genus and for understanding the evolution of its diversity.

Received 09122015 Accepted 17032016

\section{References}

Anonymous. 2010. European Pharmacopoeia, Directorate for the Quality of Medicine. European Pharmacopoeia ( $7^{\text {th }}$ ed.). Council of Europe, Strasbourg

Bagdonaite E., Martonfi P., Repcak M., Labokas J. 2010 Variation in the contents of pseudohypericin and hypericin in Hypericum perforatum from Lithuania. Biochemical Systematics and Ecology, 38: 634-640 http://dx.doi.org/10.1016/j.bse.2010.08.005
Bertoli A., Cirak C., Leonardi M., Seyis F., Pistell L. 2011. Morphogenetic changes in essential oil composition of Hypericum perforatum during the course of ontogenesis. Pharmaceutical Biology, 49: 741-751 http://dx.doi.org/10.3109/13880209.2010.545826

Bertoli A., Çirak C., Seyis F. 2015. Hypericum origanifolium Willd.: the essential oil composition of a new valuable species. Industrial Crops and Products, 77: 676-679 http://dx.doi.org/10.1016/j.indcrop.2015.08.014

Camas N., Radusiene J., Ivanauskas L., Jakstas V., Kayikcı S., Cirak C. 2014. Chemical composition of Hypericum species from the Taeniocarpium and Drosanthe sections. Plant Svstematic and Evolution, 300: 953-960 http://dx.doi.org/10.1007/s00606-013-0934-3

Chimenti F., Cottiglia F., Bonsignore L., Casu L., Casu M., Floris C., Secci D., Bolasco A., Chimenti P., Granese A., Befani O., Turini P., Alcaro S., Ortuso F., Trombetta G., Loizzo A., Guarino I. 2006. Quercetin as the active principle of Hypericum hircinum exerts a selective inhibitory activity against MAO-A: extraction, biological analysis, and computational studv. Journal of Natural Products, 69: 945-949 http://dx.doi.org/10.1021/np060015W

Ciccarelli D., Andreucci A. C., Pagni A. M. 2001. Translucent glands and secretory canals in Hypericum perforatum, Morphological, anatomical and histochemical studies during the course of onthogenesis. Annals of Botany, 88: 637-644 http://dx.doi.org/10.1006/anbo.2001.1514

Çirak C. 2006. Hypericin in Hypericum lydium Boiss. growing in Turkey. Biochemical Systematics and Ecology 34 (12): 897-899 http://dx.doi.org/10.1016/j.bse.2006.08.002

Cirak C. 2007. Seed germination protocols for ex situ conservation of some Hypericum species from Turkey. American Journal of Plant Phvsiologv. 2 (5): 287-294 http://dx.doi.org/10.3923/ajpp.2007.287.294

Cirak C., Radusiene J. 2007. Variation of hyperforin in Hypericum montbretii during its phenological cycle. Natural Product Research. 21: 1151-1156 http://dx.doi.org/10.1080/14786410701589758

Cirak C., Saglam B., Ayan A. K., Kevseroglu K. 2006. Morphogenetic and diurnal variation of hypericin in some Hypericum species from Turkey during the course of ontogenesis. Biochemical Systematics and Ecology, 34: 1-13 http://dx.doi.org/10.1016/j.bse.2005.06.004

Cirak C., Radusiene J., Janulis V., Ivanauskas L. 2007. Variation of bioactive secondary metabolites in Hypericum origanifolium during its phenological cycle. Acta Physiologiae Plantarum. 29: 197-203 http://dx.doi.org/10.1007/s11738-007-0024-7

Cirak C., Radusiene J., Janulis V., Ivanauskas L. 2010. Secondary metabolites of Hypericum confertum and their possible chemotaxonomic significance. Natural Product Communication, 5: 897-898

Cirak C., Radusiene J., Karpaviciene B., Camas N., Odabas M. S. 2013 (a). Changes in phenolic content of wild and greenhouse-grown Hypericum triquetrifolium during plant development. Turkish Turkish Journal of Agriculture and Forestry, 37: 307-314

Cirak C., Radusiene J., Camas N., Caliskan O., Odabas M. S. 2013 (b). Changes in the contents of main secondary metabolites in two Turkish Hypericum species during plant development. Pharmaceutical Biology. 51: 391-399 http://dx.doi.org/10.3109/13880209.2012.733012

Cirak C., Radusiene J., Jakstas V., Ivanauskas L., Yayla F., Seyis F., Camas N. 2016. Secondary metabolites of Hypericum species from the Drosanthe and Olympia sections. South African Journal of Botany, 104: 82-90 http://dx.doi.org/10.1016/j.sajb.2015.09.022

Crockett S. L., Robson N. K. 2011. Taxonomy and chemotaxonomy of the genus Hypericum. Medicinal and Aromatic Plant Science and Biotechnology, 5 (spec. iss. 1): 1-13

Davis P. H. 1988. Flora of Turkey and the East Aegean islands. Edinburgh, Scotland

Dona M., Dell'Aica I., Pezzato E., Sartor L., Calabrese F., Della Barbera M., Donella-Deana A., Appendino G., Borsarini A., Caniato R., Garbisa S. 2004. Hyperforin inhibits cancer invasion and metastasis. Cancer Research. 64: 6225-6232 http://dx.doi.org/10.1158/0008-5472.CAN-04-0280 
Du H., Bay B. H., Mahendran R., Olivo M. 2006. Hypericinmediated photodynamic therapy elicits differential interleukin-6 response in nasopharyngeal cancer. Cancer Letters. 235: 202-208 http://dx.doi.org/10.1016/j.canlet.2005.04.013

Feisst C., Werz O. 2004. Suppression of receptor-mediated $\mathrm{Ca} 2+$ mobilization and functional leukocyte responses by hynerforin. Biochemical Pharmacology, 67 (8): 1531-1539 http://dx.doi.org/10.1016/j.bcp.2003.12.020

Ferraz A. B. F., Schripsema J., Pohlmann A. R., von Poser G. L. 2002. Uliginosin B from Hypericum myrianthum. Biochemical Svstematics and Ecologv. 30: 989-991 http://dx.doi.org/10.1016/S0305-1978(02)00045-5

Fiebich B. L., Knörle R., Apel K., Kammler T., Weiss G. 2011. Pharmacological studies in an herbal drug combination of St. John's wort (Hypericum perforatum) and passion flower (Passiflora incarnata): in vitro and in vivo evidence of synergy between Hypericum and Passiflora in antidepressant nharmacological models. Fitoterania. 82: 474-480 http://dx.doi.org/10.1016/j.fitote.2010.12.006

Gastpar M., Zeller K. 2005. Hypericum-extrakt STW3 und Sertralin zur Behandlung der mittelschweren depression. Psychopharmakotherapie, 12: 146-153 (in German)

Guedes R. C., Eriksson L. A. 2005. Theoretical study of hypericin. Journal of Photochemistry and Photobiology A: Chemistrv. 172 (3): 293-299 http://dx.doi.org/10.1016/j.jphotochem.2004.12.025

Kasper S., Caraci F., Forti B., Drago F., Aguglia E. 2010. Efficacy and tolerability of Hypericum extract for the treatment of mild to moderate depression. European Neuropsychopharmacology. 20: 744-765 http://dx.doi.org/10.1016/j.euroneuro.2010.07.005

Khan A., Gilani A. H., Rehman N. 2011. Pharmacological studies on Hypericum perforatum fractions and constituents. Pharmaceutical Biology, 49: 46-56 http://dx.doi.org/10.3109/13880209.2010.494307
Kitanov G. M. 2001. Hypericin and pseudohypericin in some Hypericum species. Biochemical Systematics and Ecology, 29: $171-178$ http://dx.doi.org/10.1016/S0305-1978(00)00032-6

Lu H. F., Shen Z. G., Li J. Y. H., Hu Z. H. 2001. The patterns of secretory structure and their relation to hypericin content in Hypericum. Acta Botanica Sinica, 43: 1085-1088

Nogueira T., Medeiros M. A., Marcelo-Curto M. J., GarciaPerez B. E., Luna-Herrera J., Ceu Costa M. 2013. Profile of antimicrobial potential of fifteen Hypericum species from Portugal. Industrial Crops and Products. 47: 126-131 http://dx.doi.org/10.1016/j.indcrop.2013.03.005

Nunes J. M., Pinto P. S., Bordingo S. A. L., Rech S. B., Lion von Poser G. 2010. Phenolic compounds in Hypericum species from the Trigynobrathys section. Biochemical Systematics and Ecologv. 38 (2): 224-228

http://dx.doi.org/10.1016/j.bse.2010.01.010

Quassinti L., Lupidi G., Maggi F., Sagratini G., Papa F., Vittori S., Bianco A., Bramucci M. 2013. Antioxidant and antiproliferative activity of Hypericum hircinum L. subsp. majus (Aiton) N. Robson essential oil. Natural Product Research. 27: 862-868 http://dx.doi.org/10.1080/14786419.2012.677044

Sagratini G., Ricciutelli M., Vittori S., Ozturk N., Ozturk Y., Maggi F. 2008. Phytochemical and antioxidant analysis of eight Hypericum taxa from Central Italy. Fitoterapia. 79: 210-213 http://dx.doi.org/10.1016/j.fitote.2007.11.011

Schwarz D., Kisselev P., Roots 1. 2003. St. John's wort extracts and some of their constituents potently inhibit ultimate carcinogen formation from benzo [a]pyrene-7,8dihydrodiol by human CYP1A1. Cancer Research, 63: 8062-8068

Zobayed S. M. A., Freen F. A., Goto E., Kozai T. 2006. Plantenvironment interactions: accumulation of hypericin in dark glands of Hvpericum perforatum. Annals of Botany, 98: 793-804 http://dx.doi.org/10.1093/aob/mcl169

ISSN 1392-3196 / e-ISSN 2335-8947

Zemdirbyste-Agriculture, vol. 103, No. 2 (2016), p. 193-198

DOI $10.13080 /$ z-a.2016.103.025

\title{
Jonažolių rūšių antriniai metabolitai ir jų pasiskirstymas augalų dalyse
}

\author{
M. S. Odabas ${ }^{1}$, J. Radušiené2 ${ }^{2}$ L. Ivanauskas ${ }^{3}$, V. Jakštas ${ }^{3}$, N. Camas ${ }^{1}$, S. Kayikci ${ }^{4}$ \\ ${ }^{1}$ Ondokuz Mayis universiteto Bafra profesinė aukštoji mokykla, Turkija \\ ${ }^{2}$ Gamtos tyrimų centro Botanikos institutas, Lietuva \\ ${ }^{3}$ Sveikatos mokslų universiteto Medicinos akademija, Lietuva \\ ${ }^{4}$ Mustafa Kemal universitetas, Turkija
}

\section{Santrauka}

Hypericum genties (Hypericaceae) augalai sulaukia vis didesnio susidomėjimo dèl ju kaupiamu ivairių biologiškai aktyvių junginių. Tyrimo metu buvo nustatyta kai kurių antrinių metabolitų sudetis Hypericum hircinum L. subsp. majus (Ainton) N. Robson, H. pallens Banks et Sol., H. russegger (Fenzl) R. Keller ir H. lanuginosum Lam. augaluose jų žydejjimo metu. Surinkta žaliava buvo suskirstyta pagal augalo dalis ir analizuota efektyviosios skysčių chromatografijos metodu. Nustatyti junginių kiekiai ịvairavo priklausomai nuo augalų rūšių ir jų dalių. Žiedai sukaupe didesnius kiekius junginių, išskyrus neochlorogeninę, kavos ir 2,4-dihidroksibenzojinę rūgštis, kurios dominavo lapuose. H. hircinum nekaupé kvercitrino ir avikularino, H. lanuginosum - hyperforino ir kavos rūgšties, o rutinas buvo aptiktas tik $H$. pallens augaluose.

Pirmą kartą buvo nustatyta ir įvertinta Turkijoje augančių jonažolių bioaktyvių junginių sudètis. Gauti tyrimų duomenys galès būti panaudoti biologiniams ir cheminiams jonažolių genties augalų tyrimams ir papildys žinias apie šios genties augalų cheminę sudètį.

Reikšminiai žodžiai: cheminė sudètis, fenolinès rūgštys, flavonolai, floroglucinolai, Hypericum hircitum, H. lanuginosum, H. pallens, $H$. russeggeri, naftodiantronai.

Please use the following format when citing the article:

M. S. Odabas, J. Radusiene, L. Ivanauskas, V. Jakstas, N. Camas, S. Kayikci. 2016. Secondary metabolites in Hypericum species and their distribution in different plant parts. Zemdirbyste-Agriculture, 103 (2): 193-198 DOI 10.13080/z-a.2016.103.025 